\title{
Impact of Sustained Virological Response on Metabolic Changes and Vitamin-D Status in Patients with Hepatitis C Viral Infection Treated by Direct Acting Antiviral drugs
}

\author{
Zainab Gaber Mahran ${ }^{1}$, Laila Abd Elbaki Mohammed ${ }^{1}$, Mohammed \\ Hassan Abdelgawad ${ }^{2}$, Ghada Abdelrahman Mohamed ${ }^{3}$ \\ ${ }^{1}$ Department of Gastroenterology and Tropical Medicine, Faculty of Medicine, Assiut \\ University, Assuit, Egypt. \\ ${ }^{2}$ Department of Gastroenterology, Assuit Police Hospital, Assuit, Egypt \\ ${ }^{3}$ Department of Internal Medicine, Faculty of Medicine, Assuit University, Assuit, \\ Egypt.
}

Corresponding Author Mohammed Hassan Abdelgawad.

Mobile:

$+201008778754$

E mail:

samah.soliman@ med.tanta.edu.eg

Key words: Vitamin D, insulin resistance, direct acting analogues, lipid profile.
Background and aim: Hepatitis $C$ virus (HCV) clearance is linked to better glycometabolic management in such individuals. The introduction of direct acting analogues (DAAs) in the previous decade has resulted in a significant improvement in the management of chronic hepatitis $\mathrm{C}$ infection. Until date, there has been a scarcity of research on the effects of these drugs on vitamin D (VD), lipid profile, and insulin resistance (IR).

Patients and Methods: In between April 2019 to February 2020, a cross sectional study was conducted on 100 patients with known chronic hepatitis infection and was eligible to therapy with DAAs. Lipid profile, vitamin $\mathrm{D}$ and insulin resistance was assessed at baseline and 3-months after therapy.

Results: Ninety percent of enrolled patients achieved sustained viral response (SVR). There were no significant changes in lipid profile after therapy with DAAs but at the same time IR was significantly decreased while VD was significantly increased.

Conclusion: Therapy with DAAs is effective in achievement of SVR and also, it could have beneficial effects on insulin resistance and vitamin D. Long term prospective studies on large scale are needed.

\section{INTRODUCTION}

$\mathrm{HCV}$ is a leading cause of chronic liver disease, with millions of individuals globally affected by its consequences. The recent discovery of a new class of direct-acting antivirals (DAA) has resulted in a cure rate of more than 90 percent. $\mathrm{HCV}$ eradication has been found to improve hepatic inflammation and functioning within a few months after cure, along with hepatic fibrosis [1].

Vitamin D (VD) insufficiency is the most prevalent dietary deficiency, affecting millions of individuals throughout the world. Aside from a lack of sunshine exposure, chronic liver illness and genetic variations in the genes involved in VD metabolism are the leading causes of VD insufficiency. VD is largely engaged in calcium homeostasis, but it also plays key functions in the immune system, cell differentiation, and proliferation [2].

VD deficiency is frequent in individuals with chronic hepatitis $\mathrm{C}$ (CHC), with a frequency close to $90 \%$. Chronic liver disorders are one source of VD insufficiency, and the degree varies depending on the severity of the condition. Reduced liver metabolic functions as a result of hepatic damage and fibrosis are one potential explanation for this deficiency [3].

The achievement of SVR decreases the risk of liver-related complications, liver transplantation, and mortality substantially. Despite earlier research indicating a decrease in cardiovascular events in SVR patients, 
new research suggests that $\mathrm{HCV}$ eradication may have an influence on certain comorbidities by raising total cholesterol serum levels and fractions. However, long-term evaluation of lipid profile and concomitant medication are unknown in patients with HCV cure after DAA [4-6].

The current work was designed to evaluate change in lipid profile and IR in addition to level of VD in patients with $\mathrm{CHC}$ infection treated by direct acting antiviral agents.

\section{Patients AND METHODS}

\section{Study setting and design}

A cross sectional study was conducted at Outpatient Clinic of Tropical Medicine and Gastroenterology Department. It was conducted in the period from April 2019 to February 2020.

\section{Inclusion\& exclusion criteria}

Any patient with chronic HCV infection and was eligible for treatment with DAAs was recruited in the study. The exclusion criteria included; diabetes mellitus, VD supplements within the last 3 months, decompensated liver cirrhosis, coinfection with hepatitis B virus (HBV) or human immunodeficiency virus, autoimmune diseases, history of steroid or immunosuppressive therapy, or patient's refusal

\section{Methodology}

The current study enrolled 100 patients with chronic HCV infection were diagnosed based on detectable HCV RNA with anti-HCV antibodies. All were subjected to complete history taking thorough clinical evaluation. Before initiation of therapy and three months after therapy; all patients were evaluated with abdominal ultrasound.

Also, the following laboratory data were ordered (at baseline and three months after therapy); complete blood count (CBC), liver function test, alpha fetoprotein, lipid profile, serum creatinine, random blood sugar (RBS). Also, insulin resistance determined via Homeostasis Model Assessment

$($ HOMA-IR $)=$ fasting insulin $(\mu \mathrm{u} / \mathrm{ml}) \times$ fasting glucose $(\mathrm{mg} / \mathrm{dl}) / 405$

An index value of $>2.5$ was defined as IR. [7].

\section{Measurement of VD level}

Level of VD was assessed by the Liaison $25(\mathrm{OH})$ VD total assay (DiaSorin, Saluggia, Italy), which was performed on the LIAISON® chemiluminescence analyzer following the manufacturer's instructions. Final concentrations are reported in $\mathrm{ng} / \mathrm{mL}$.

According to the Endocrine Society Practice Guidelines, the criteria for VD insufficiency/deficiency was defined as serum $25(\mathrm{OH}) \quad \mathrm{VD}<30 \mathrm{ng} / \mathrm{mL}$. Serum $25(\mathrm{OH}) \quad \mathrm{VD}$ concentrations $<20 \mathrm{ng} / \mathrm{mL}$ and between 20 and $29 \mathrm{ng} / \mathrm{mL}$ were defined as VD deficiency and VD insufficiency, respectively [8].

\section{Statistical analysis}

Baseline characteristics are presented as the percentage or mean \pm standard deviation (SD). Categorical variables were analyzed using $c h i^{2}$ test. Continuous variables with a normal distribution were compared within the same group (pre- and post-treatment) with paired t-test while comparison between different groups was done by Student $t$ test. The normality of was assessed by Shapiro-Wilks test. All statistical analyses were performed in SPSS Version 22.0 (IBM Corp., Armonk, NY, USA). Differences were considered significant at $\mathrm{p}<0.05$

\section{RESULTS:}

\section{Baseline and follow up data of studied group (table 1):}

Mean age of enrolled patients was $40.75 \pm 11.86$ years and majority (74\%) of them was males. All patients received therapy for three months duration where majority of them $(90 \%)$ received only sofosbuvir and daclatasvir while in 10 $(10 \%)$ patients weight based ribavirin was added.

Nearly all patients showed normalization of aspartate transaminase and alanine transaminase. After therapy, there was significant reduction in HOMA (8.48 \pm 2.98 vs. $5.06 \pm 1.35 ; p<0.001)$. It was found that level of VD was significantly increased after DAAs therapy $(27.56 \pm 2.22 \mathrm{vs}$. $17.29 \pm 4.56(\mathrm{ng} / \mathrm{ml}) ; p=0.01)$.

\section{Change in lipid profile, VD and HOMA based on sustained virological response (table 2):}

Out of the enrolled patients; 90 (90\%) patients achieved 3-months SVR while 10 (10\%) patients failed to achieve SVR. All baseline and 3-months 
after therapy laboratory data showed no significant diffrences between both groups of patients with exception of significantly lower HOMA (4.56 \pm 1.45 vs. $8.06 \pm 2.22 ; p<0.001)$ and higher VD $(29.45 \pm 3.09$ vs. $19.50 \pm 2.98$ $(\mathrm{ng} / \mathrm{ml}) ; p<0.001)$ at 3 -months after therapy among patients who achieved SVR.

It was found that $25(27.8 \%)$ patients from those achieved SVR and 2 (20\%) patients from those didn't achieve SVR had sufficient VD after therapy. Also, after therapy majority of both groups had insufficient VD.

In each separate group, there is no significant change in such parameters at $3^{\text {rd }}$ month after therapy with exception of significant reduction in HOMA with significant increase in vitamin D in SVR group only.
Level of vitamin $D$ in cirrhotic and noncirrhotic patients (table 3):

Patients with liver cirrhosis had significantly higher HOMA at baseline $(8.99 \pm 2.11$ vs. $6.56 \pm$ $2.01 ; p=0.04)$ and at 3 -months after therapy $(7.89$ \pm 3.11 vs. $3.45 \pm 1.10 ; p<0.001$ ) in comparison to those non-cirrhotic patients. Although baseline VD showed no significant difference between both groups, non-cirrhotic patients had significant higher VD at 3-months after therapy $(26.11 \pm 2.11$ vs. $20.20 \pm 3.09(\mathrm{ng} / \mathrm{ml}) ; p<$ $0.001)$.

In each separate group, there is no significant change in HOMA and vitamin D at $3^{\text {rd }}$ month after therapy with exception of significant reduction in HOMA with significant increase in vitamin D in non-cirrhotic group only.

Table (1): Baseline and follow up data of studied groups.

\begin{tabular}{|c|c|c|c|}
\hline Item & $\begin{array}{c}\text { Baseline data } \\
(n=100)\end{array}$ & $\begin{array}{l}\text { 3-months after therapy } \\
(n=100)\end{array}$ & $P$ value \\
\hline Age (years) & $40.75 \pm 11.86$ & & \\
\hline Male sex & $74(74 \%)$ & & \\
\hline BMI $\left(\mathrm{kg} / \mathrm{m}^{2}\right)$ & $27.59 \pm 3.37$ & & \\
\hline $\begin{array}{l}\text { Regimens of therapy } \\
\text { SOF\& Dacl } \\
\text { SOF and Dacl with RIB }\end{array}$ & $\begin{array}{l}90(90 \%) \\
10(10 \%)\end{array}$ & & \\
\hline Leucocytes $\left(10^{3} / \mathrm{ul}\right)$ & $6.23 \pm 1.85$ & $7.21 \pm 1.09$ & 0.22 \\
\hline Hemoglobin $(\mathrm{mg} / \mathrm{dl})$ & $12.50 \pm 1.44$ & $11.51 \pm 1.04$ & 0.98 \\
\hline Platelets $\left(10^{3} / \mathrm{ul}\right)$ & $215.96 \pm 79.14$ & $211.06 \pm 60.45$ & 0.20 \\
\hline Bilirubin $(\mathrm{mg} / \mathrm{dl})$ & $0.81 \pm 0.69$ & $0.87 \pm 0.19$ & 0.45 \\
\hline AST $(\mathrm{u} / \mathrm{l})$ & $45.55 \pm 13.98$ & $22.15 \pm 6.78$ & $<0.001$ \\
\hline $\operatorname{ALT}(\mathrm{u} / \mathrm{l})$ & $52.15 \pm 11.43$ & $29.23 \pm 8.67$ & $<0.001$ \\
\hline Serum albumin $(\mathrm{g} / \mathrm{dl})$ & $4.11 \pm 0.41$ & $4.14 \pm 0.21$ & 0.34 \\
\hline INR & $1.10 \pm 0.13$ & $1.09 \pm 0.12$ & 0.19 \\
\hline AFP (ng/dl) & $9.98 \pm 1.07$ & $7.67 \pm 2.11$ & 0.37 \\
\hline Creatinine $(\mathrm{mg} / \mathrm{dl})$ & $0.74 \pm 0.16$ & $0.78 \pm 0.10$ & 0.16 \\
\hline Cholesterol (mg/dl) & $170.32 \pm 30.50$ & $169.12 \pm 22.45$ & 0.09 \\
\hline Triglyceride $(\mathrm{mg} / \mathrm{dl})$ & $152.83 \pm 32.6$ & $160.22 \pm 21.11$ & 0.10 \\
\hline $\mathrm{HDL}(\mathrm{mg} / \mathrm{dl})$ & $38.32 \pm 11.90$ & $34.22 \pm 9.11$ & 0.22 \\
\hline $\mathrm{LDL}(\mathrm{mg} / \mathrm{dl})$ & $98.54 \pm 13.35$ & $101.11 \pm 5.91$ & 0.33 \\
\hline RBS (mg/dl) & $109.78 \pm 10.45$ & $100.18 \pm 9.09$ & 0.06 \\
\hline HOMA & $8.48 \pm 2.98$ & $5.06 \pm 1.35$ & $<0.001$ \\
\hline $\begin{array}{l}\text { Vitamin D }(\mathrm{ng} / \mathrm{ml}) \\
\text { Level of vitamin D }\end{array}$ & $17.29 \pm 4.56$ & $27.56 \pm 2.22$ & $\begin{array}{l}0.01 \\
0.02\end{array}$ \\
\hline Sufficient & $17(67.0 \%)$ & $27(27 \%)$ & \\
\hline Insufficient & $59(29.0 \%)$ & $60(29.0 \%)$ & \\
\hline Deficient & $24(4.0 \%)$ & $13(4.0 \%)$ & \\
\hline
\end{tabular}

Data was expressed as mean (SD), frequency (percentage). $P$ value was significant if $<0.05$. BMI: body mass index; AST: aspartate transaminase; ALT: alanine transaminase; INR: international randomized ratio; AFP: alpha feto-protein; LDL: low density lipoprotein; HDL: high density lipoprotein; RBS: fasting blood sugar; IR: insulin resistance; HOMA: homeostatic model assessment. 
Table (2): Lipid profile, VD and HOMA based on sustained virological response.

\begin{tabular}{|c|c|c|c|}
\hline Item & SVR group $(n=90)$ & No-SVR group $(n=10)$ & $P$ value $^{2}$ \\
\hline $\begin{array}{l}\text { Cholesterol (mg/dl) } \\
\text { Baseline } \\
\text { 3-month after therapy } \\
P \text { value }^{2}\end{array}$ & $\begin{array}{c}168.13 \pm 24.56 \\
165.35 \pm 21.11 \\
0.44\end{array}$ & $\begin{array}{c}171.23 \pm 29.08 \\
170.12 \pm 27.67 \\
0.50\end{array}$ & $\begin{array}{l}0.11 \\
0.86\end{array}$ \\
\hline $\begin{array}{l}\text { Triglyceride }(\mathbf{m g} / \mathbf{d l}) \\
\text { Baseline } \\
\text { 3-month after therapy } \\
P \text { value }\end{array}$ & $\begin{array}{c}150.81 \pm 45.67 \\
156.78 \pm 22.34 \\
0.09 \\
\end{array}$ & $\begin{array}{c}155.67 \pm 29.56 \\
161.20 \pm 25.67 \\
0.07 \\
\end{array}$ & $\begin{array}{l}0.16 \\
0.17\end{array}$ \\
\hline $\begin{array}{l}\text { HDL }(\mathbf{m g} / \mathbf{d l}) \\
\text { Baseline } \\
\text { 3-month after therapy } \\
\boldsymbol{P} \text { value }^{2}\end{array}$ & $\begin{array}{c}40.11 \pm 13.56 \\
33.40 \pm 12.34 \\
0.10\end{array}$ & $\begin{array}{c}35.09 \pm 12.34 \\
37.11 \pm 7.89 \\
0.23\end{array}$ & $\begin{array}{l}0.92 \\
0.15\end{array}$ \\
\hline $\begin{array}{l}\text { LDL }(\mathbf{m g} / \mathbf{d l}) \\
\text { Baseline } \\
\text { 3-month after therapy } \\
P \text { value }\end{array}$ & $\begin{array}{c}97.11 \pm 10.34 \\
99.87 \pm 8.89 \\
0.20\end{array}$ & $\begin{array}{c}100.45 \pm 9.98 \\
105.10 \pm 7.80 \\
0.64\end{array}$ & $\begin{array}{l}0.93 \\
0.54\end{array}$ \\
\hline $\begin{array}{l}\text { HOMA } \\
\text { Baseline } \\
\text { 3-month after therapy } \\
\boldsymbol{P} \text { value }^{2}\end{array}$ & $\begin{array}{c}8.11 \pm 3.98 \\
4.56 \pm 1.45 \\
\mathbf{0 . 0 1}\end{array}$ & $\begin{array}{c}9.01 \pm 2.01 \\
8.06 \pm 2.22 \\
0.07\end{array}$ & $\begin{array}{c}0.33 \\
<\mathbf{0 . 0 0 1}\end{array}$ \\
\hline $\begin{array}{l}\text { Vitamin D }(\mathbf{n g} / \mathbf{m l}) \\
\text { Baseline } \\
\text { 3-month after therapy } \\
\boldsymbol{P}_{\text {value }}\end{array}$ & $\begin{array}{c}18.29 \pm 2.56 \\
29.45 \pm 3.09 \\
\mathbf{0 . 0 3} \\
\end{array}$ & $\begin{array}{c}16.05 \pm 3.33 \\
19.50 \pm 2.98 \\
0.19\end{array}$ & $\begin{array}{c}0.16 \\
<\mathbf{0 . 0 0 1}\end{array}$ \\
\hline $\begin{array}{l}\text { Level of vitamin D } \\
\text { At baseline } \\
\text { Sufficient } \\
\text { Insufficient } \\
\text { Deficient } \\
\text { 3-month after therapy } \\
\text { Sufficient } \\
\text { Insufficient } \\
\text { Deficient } \\
P \text { value }^{2}\end{array}$ & $\begin{array}{c}15(16.7 \%) \\
41(45.6 \%) \\
34(37.7 \%) \\
\\
25(27.8 \%) \\
55(61.1 \%) \\
10(11.1 \%) \\
\mathbf{0 . 0 4}\end{array}$ & $\begin{array}{c}2(20 \%) \\
4(40 \%) \\
4(40 \%) \\
2(20 \%) \\
5(50 \%) \\
3(30 \%) \\
0.11\end{array}$ & 0.01 \\
\hline
\end{tabular}

Data was expressed as mean (SD), frequency (percentage). P value was significant if < 0.05. LDL: low density lipoprotein; HDL: high density lipoprotein; RBS: fasting blood sugar; HOMA: homeostatic model assessment. $\mathrm{P}$ value1compared between both groups at different times while $\mathrm{P}$ value 2 compared between baseline and f3month after therapy data in the same group

Table (3): Level of vitamin D in cirrhotic and non-cirrhotic patients .

\begin{tabular}{|c|c|c|c|}
\hline & Non-cirrhotic $(n=90)$ & Cirrhotic $(n=10)$ & $P$ value $^{1}$ \\
\hline $\begin{array}{l}\text { Vitamin D }(\mathbf{n g} / \mathbf{m l}) \\
\text { Baseline } \\
\text { 3-month after therapy } \\
\boldsymbol{P} \text { value }^{2} \\
\end{array}$ & $\begin{array}{l}16.29 \pm 2.98 \\
26.11 \pm 2.11 \\
\quad<\mathbf{0 . 0 0 1} \\
\end{array}$ & $\begin{array}{c}18.11 \pm 3.11 \\
20.20 \pm 3.09 \\
0.33 \\
\end{array}$ & $\begin{array}{c}0.16 \\
<\mathbf{0 . 0 0 1}\end{array}$ \\
\hline $\begin{array}{l}\text { HOMA } \\
\text { Baseline } \\
\text { 3-month after therapy } \\
\boldsymbol{P} \text { value }^{2}\end{array}$ & $\begin{array}{c}6.56 \pm 2.01 \\
3.45 \pm 1.10 \\
0.02\end{array}$ & $\begin{array}{c}8.99 \pm 2.11 \\
7.89 \pm 3.11 \\
0.10\end{array}$ & $\begin{array}{c}0.04 \\
<0.001\end{array}$ \\
\hline
\end{tabular}

Data was expressed as mean (SD. $P$ value was significant if $<0.05$. HOMA: homeostatic model assessment.

$P$ value ${ }^{1}$ compared between both groups at different times while $P$ value ${ }^{2}$ compared between baseline and f3month after therapy data in the same group 


\section{DISCUSSION}

DAA regimens are the current standard of therapy in patients with $\mathrm{CHC}$ infection, curing more than $95 \%$ of cases. Patients with $\mathrm{CHC}$, particularly those with cirrhosis, have a high frequency of comorbidities, which necessitate the administration of several medicines in addition to antiviral therapy [9].

The current study was conducted on 100 patients with chronic HCV infection who were eligible for therapy with DAAs. The study aimed to determine change in VD, lipid profile and IR as assessed by HOMA following DAAs and impact of these parameters among those patients.

In the current study SVR was achieved in $90 \%$. In 2016, EASL issued guidelines for treatment of HCV genotype 4by including the combination of sofosbuvir and daclatasvir with or without ribavirin for 12 weeks [10]. This result was consistent with many previous reported studies that reported efficacy of this combination in management of HCV infection [11-13].

VD is a necessary hormone substance that plays a role in normal organ physiology as well as pathophysiology in a variety of illnesses. VD insufficiency and deficiency are common in individuals with chronic liver disorders, and they increase as hepatic function and cirrhosis severity worsen [14].

In our study, level of VD was increased following DAAs. Also, we found that level of VD following DAAs was significantly higher among non-cirrhotic patients and also, in those who achieved SVR. Longer VD level monitoring is required to explore this hypothesis. Nevertheless, the most crucial result of the present study is that level VD may be increased following therapy with DAAs.

In consistent with our study, Patients with chronic hepatitis exhibited substantially greater levels of VD at baseline or throughout follow-up than those with liver cirrhosis. This study disagreed with the current study as regard significant reduction of VD following DAAs at 3- and 6- months after therapy [15].

VD deficiency following DAA treatment, according to the authors, might be explained by other underlying variables rather than impaired metabolic liver function. To put it another way, decreased liver function may not be a substantial contributor to this nutritional deficiency in individuals with $\mathrm{CHC}$ infection [15].

However, a study indicated a tendency toward a decreased incidence of VD deficiency 24 weeks after interferon therapy completion. This finding implies that restoring hepatic VD metabolism, particularly 25 -alpha hydroxylation, may take time before showing therapeutic benefit [16].

The impact of VD on chronic liver disorders, independent of etiology, has been fully documented in several researches. In individuals with chronic hepatitis B, serum VD levels were inversely linked to HBV viral load [17]. Low blood $25(\mathrm{OH})$ VD levels were linked with advanced illness and a predictor of responsiveness to ursodeoxycholic acid in individuals with primary biliary cholangitis [18].

Low serum VD levels were also linked to severe histological characteristics and may have predicted negative treatment results in autoimmune hepatitis patients. VD insufficiency has numerous negative consequences in $\mathrm{CHC}$ patients, including deregulation of T-cell activities, which results in poorer response rates of $\mathrm{HCV}$ genotype 1 to pegylated interferon and RBV therapy [19].

Our investigation found that the lipid profile of the subjects exhibited no significant changes three months following DAA treatment. However, we discovered that following treatment, insulin resistance as measured by HOMA improved considerably. In addition, patients who achieved SVR and those who did not have cirrhosis had considerably reduced HOMA following treatment.

Few researches have been conducted to investigate the effects of SVR on glucose and lipid metabolism, and the evidence that is available is both inadequate and inconsistent. Notably, a study proposed that DAA-induced fast suppression of $\mathrm{HCV}$ core proteins may result in a dysregulation of host lipid metabolism, shown as a reduction in lipid droplet formation in $\mathrm{HCV}$-infected liver cells and a significant rebound of circulating $\mathrm{HCV}$ core proteins [20].

Other study revealed irrespective of DAA protocol or fibrotic state, viral clearance caused a substantial reduction in insulin resistance as evaluated by HOMA, a rise in total cholesterol, low density lipoproteins (LDL), the LDL/high density lipoproteins (HDL) ratio, and non-HDL 
cholesterol. Notably, the detrimental effect on the lipid profile may be offset in part by the reduction in insulin [21].

To the best of our knowledge, this is the first research to look at all three indicators (VD, lipid profile, and IR) in a single prospective cohort of patients with $\mathrm{CHC}$ who were given DAAs. However, the current study has two major limitations: a small sample size and a short follow-up period.

In conclusion, DAA treatment was found to be safe and effective in patients with chronic hepatitis $\mathrm{C}$ infection, but the effect of those drugs on VD, lipid profile, and insulin resistance remains unknown and controversial. Future research on this topic with long-term follow-up are thus needed.

Ethical consideration: This work was conducted in accordance with Code of Good Practice and the guidelines of Declaration of Helsinki, $7^{\text {th }}$ revision, 2013 and after being approved by the Medical Ethics Committee with No. 17200294. Also, a written informed consent was obtained from all participants before being enrolled in the study.

\section{Abbreviations}

DAAs: direct acting analogues, VD: vitamin D, SVR: sustained virological response, IR: insulin resistance, HOMA: homeostatic model assessment.

Funding: None, Author funded.

Conflict of interest: None.

\section{HIGHLIGHTS}

1. Low serum VD level was an independent predictor for insulin resistance among patients with $\mathrm{HCV}$-induced patients.

2. VD favors the HCV response by improving the sensitivity to insulin. Insulin resistance (IR) is considered one of the factors in predicting HCV patients' response.

3. Vitamin D deficiency may be linked to a lack of response to anti-viral treatment, while vitamin D supplementation may potentiate SVR.

\section{REFERENCES}

1. Curry MP, O’Leary JG, Bzowej N, Muir AJ, Korenblat KM, Fenkel JM, et al. Sofosbuvir and velpatasvir for $\mathrm{HCV}$ in patients with decompensated cirrhosis. New England Journal of Medicine 2015 Dec 31; 373(27):2618-28.

2. Ding N, Ruth TY, Subramaniam N, Sherman $\mathrm{MH}$, Wilson C, Rao R, et al. A vitamin D receptor/SMAD genomic circuit gates hepatic fibrotic response. Cell 2013 Apr 25; 153(3):60113 .

3. Kitson MT, Roberts SK. D-livering the message: the importance of vitamin D status in chronic liver disease. Journal of Hepatology 2012 Oct 1; 57(4):897-909.

4. Nahon P, Bourcier V, Layese R, Audureau E, Cagnot C, Marcellin P, et al. Eradication of hepatitis $\mathrm{C}$ virus infection in patients with cirrhosis reduces risk of liver and non-liver complications. Gastroenterology 2017 Jan 1; 152(1):142-56.

5. Hashimoto S, Yatsuhashi H, Abiru S, Yamasaki K, Komori A, Nagaoka S, et al. Rapid increase in serum low-density lipoprotein cholesterol concentration during hepatitis $\mathrm{C}$ interferon-free treatment. PLoS One 2016; 11:e0163644.

6. Kanda T, Moriyama M. Direct-acting antiviral agents against hepatitis $\mathrm{C}$ virus and lipid metabolism. World J Gastroenterol 2017; 23:5645-5649.

7. Qu HQ, Li Q, Rentfro AR, Fisher-Hoch SP, McCormick JB. The definition of insulin resistance using HOMA-IR for Americans of Mexican descent using machine learning. PloS one 2011 Jun 14; 6(6):e21041.

8. Holick MF, Binkley NC, Bischoff-Ferrari HA, Gordon CM, Hanley DA, Heaney RP, et al. Evaluation, treatment, and prevention of vitamin D deficiency: an Endocrine Society clinical practice guideline. J Clin Endocrinol Metab 2011;96(7):1911-30

9. González-Colominas E, Batlle M, MongeEscartín I, Duran X, Viu A, de Antonio-Cuscó M, et al. Impact of $\mathrm{HCV}$ cure with drug-acting antivirals in the use of concomitant medication and lipid profile: follow-up data 2 years after the sustained virological response. European Journal of Gastroenterology \& Hepatology 2021 Feb 1; 32(2):214-22.

10. EASL. Recommendations on treatment of hepatitis C. J Hepatol 2016; 66(1):153-94. 
11. Mark S. Sulkowski, David F. Gardiner, Maribel Rodriguez-Torres, M., K. Rajender Reddy, Tarek Hassanein, Ira Jacobson, et al. Daclatasvir plus sofosbuvir for previously treated or untreated chronic HCV infection. N Engl J Med 2014; 370:211-21.

12. Abdel-Moneim A, Aboud A, Abdel-Gabaar M, Zanaty MI, Ramadan M. Efficacy and safety of sofosbuvir plus daclatasvir with or without ribavirin: large real-life results of patients with chronic hepatitis $\mathrm{C}$ genotype 4. Hepatology International. $2018 \mathrm{Jul}$; 12(4):348-55.

13. David R Nelson, James N Cooper, Jacob $P$ Lalezari, Eric Lawitz, Paul J Pockros, Norman Gitlin, et al. All-oral 12-week treatment with daclatasvir plus sofosbuvir in patients with hepatitis $\mathrm{C}$ virus genotype3 infection: ALLY-3 phase III study. Hepatology 2015; 61:1127-35.

14. Petta $\mathrm{S}$, Cammà $\mathrm{C}$, Scazzone $\mathrm{C}$, Tripodo $\mathrm{C}, \mathrm{Di}$ Marco V, Bono A, et al. Low vitamin D serum level is related to severe fibrosis and low responsiveness to interferon-based therapy in genotype 1 chronic hepatitis C. Hepatology 2010 Apr; 51(4):1158-67.

15. Sriphoosanaphan S, Thanapirom K, Suksawatamnuay S, Thaimai P, Sittisomwong S, Sonsiri K, et al. Changes in hepatic fibrosis and vitamin $\mathrm{D}$ levels after viral hepatitis $\mathrm{C}$ eradication using direct-acting antiviral therapy. $B M C$ Gastroenterology 2020 Dec; 20(1):1-0.
16. Lange CM, Bojunga J, Ramos-Lopez E, von Wagner M, Hassler A, Vermehren $J$, et al. Vitamin D deficiency and a CYP27B1-1260 promoter polymorphism are associated with chronic hepatitis $\mathrm{C}$ and poor response to interferon-alfa based therapy. Journal of Hepatology 2011 May 1; 54(5):887-93.

17. Hu YC, Wang WW, Jiang WY, Li CQ, Guo JC, Xun YH. Low vitamin D levels are associated with high viral loads in patients with chronic hepatitis B: a systematic review and metaanalysis. BMC Gastroenterol 2019; 19(1):84.

18. Guo GY, Shi YQ, Wang L, Ren X, Han ZY, Guo $\mathrm{CC}$, et al. Serum vitamin D level is associated with disease severity and response to ursodeoxycholic acid in primary biliary cirrhosis. Aliment Pharmacol Ther 2015; 42(2):221-30.

19. Efe C, Kav T, Aydin C, Cengiz M, Imga NN, Purnak T, et al. Low serum vitamin D levels are associated with severe histological features and poor response to therapy in patients with autoimmune hepatitis. Dig Dis Sci 2014; 59(12):3035-42.

20. Eaton SL, Roche SL, Llavero Hurtado M, Oldknow KJ, Farquharson C, Gillingwater TH, et al. Total protein analysis as a reliable loading control for quantitative fluorescent Western blotting. PloS one 2013 Aug 30; 8(8):e72457.

21. Gitto S, Cicero AF, Loggi E, Giovannini M, Conti F, Grandini E, et al. Worsening of serum lipid profile after direct acting antiviral treatment. Annals of Hepatology 2018 Mar 27; 17(1):64-75. 